\title{
ВЫШЛА В СВЕТ НАУЧНАЯ МОНОГРАФИЯ «ДРАМАТУРГИЯ А. С. ПУШКИНА: ПРОБЛЕМА СЦЕНИЧНОСТИ»
}

\author{
Б. Н. Гайдин \\ (Московский гуманитарный университет)
}

Аннотация: В статье анонсируется издание 2015 года - коллективная научная монография «Драматургия А. С. Пушкина: проблема сиеничности» (авторы - Н. В. Захаров, Вал. А. Луков, Вл. А. Луков).

Ключевые слова: аннотация; издание; А. С. Пушкин; тезаурусный подход; Московский гуманитарный университет; проблема сценичности

\section{“A.S. PUSHKIN'S DRAMATIC ART: THE PROBLEM OF STAGINESS": A NEW MONOGRAPH}

\author{
B. N. Gaydin \\ (Moscow University for the Humanities)
}

\begin{abstract}
This short piece announces the publication of a collective monograph “A.S. Pushkin's Dramatic Art: The Problem of Staginess" (2015) which presents the outcomes of a Russian Foundation for the Humanities-supported project. The book was edited by N.V. Zakharov, Val.A. Lukov, Vl.A. Lukov.

Keywords: blurb; monograph; A.S. Pushkin; thesaurus approach; Moscow University for the Humanities; problem of staginess
\end{abstract}

24 июня 2016 г. в рамках научной сессии Института фундаментальных и прикладных исследований Московского гуманитарного университета «Улучшение человека: современные философские концепции» состоялась презентация коллективной научной монографии «Драматургия А.С.Пушкина: проблема сценичности» (Захаров, Луков Вал., Луков В., 2015). Монография вышла в издательстве Московского гуманитарного университета в 2015 г.

В монографии анализируется парадоксальная «несценическая» сценичность драматургии А. С. Пушкина. Применяя методологию тезаурусного подхода, авторы монографии показывают, как через осознание шекспиризма Пушкин открыл новую сценичность, которая выходит за пределы традиционной театральной сценичности и может рассматриваться как феномен русской культуры. 
Монография подготовлена по результатам исследования в рамках проекта Российского гуманитарного научного фонда (РГНФ, № 13-0400346, «Драматургия А. С. Пушкина: проблема сценичности»). Авторы монографии: доктор философии (PhD), кандидат филологических наук, руководитель проекта РГНФ Н. В. Захаров; доктор философских наук, профессор, заслуженный деятель науки РФ Вал. А. Луков; доктор филологических наук, профессор, заслуженный деятель науки РФ Вл. А. Луков (1948-2014). Некоторые материалы, подготовленные участниками проекта кандидатом культурологии С. В. Арониным, кандидатом филологических наук В. С. Макаровым, музыковедом О. А. Захаровой, также включены в текст монографии.

Рецензентами выступили: доктор филологических наук, профессор В. П. Трыков, доктор культурологии, доктор философских наук, професcop А. В. Костина, доктор филологических наук, профессор А. Р. Ощепков.

Книга предназначена для исследователей в области философии и социологии культуры, культурологии, литературоведения, искусствоведения, аспирантов и студентов гуманитарного профиля.

\section{СПИСОК ЛИТЕРАТУРЫ}

Захаров, Н. В., Луков, Вал. А., Луков, Вл. А. (2015) Драматургия А.С.Пушкина: проблема сценичности. М. : Изд-во Моск. гуманит. ун-та. 412 c. ISBN 978-5-906822-63-5

Гайдин Борис Николаевич - кандидат философских наук, заместитель директора Центра теории и истории культуры Института фундаментальных и прикладных исследований Московского гуманитарного университета. Адрес: 111395, Россия, г. Москва, ул. Юности, д. 5, корп. 6. Тел.: +7 (499) 374-59-30. Эл. адрес: barbarious@mail.ru

Gaydin Boris Nikolaevich, Candidate of Philosophy, Deputy Director, Center for the Theory and History of Culture, Institute for Fundamental and Applied Studies, Moscow. Postal address: Bldg.6, 5 Yunosti St., 111395 Moscow, Russian Federation.Tel.+7 (499) 374-59-30.Email: barbarious@mail.ru 